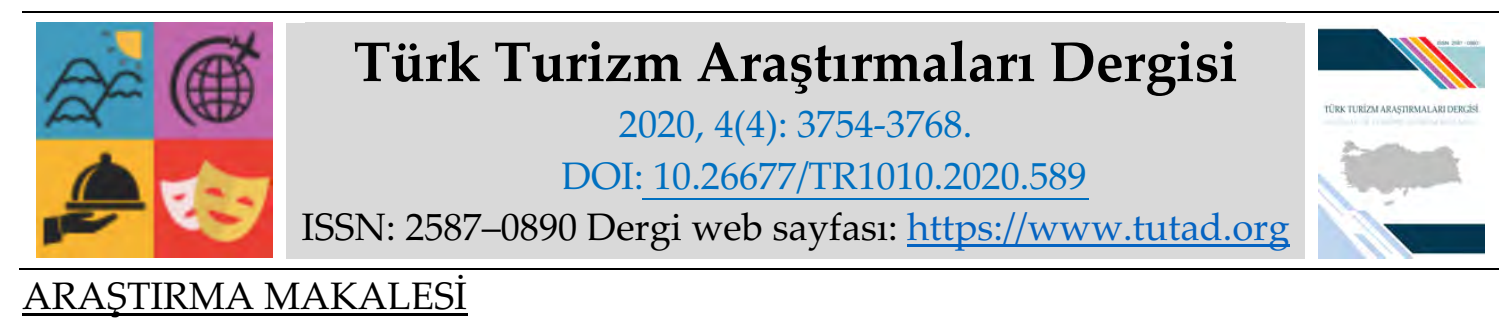

\title{
Tip 1 Diyabetli Bireylerin Yiyecek İçecek İşletmelerinden Beklentileri Üzerine Bir Araştırma
}

\begin{abstract}
Ahmet Selçuk GÜRKAN, Doktora Öğrencisi, Sakarya Uygulamalı Bilimler Üniversitesi, Turizm Fakültesi, Sapanca, e-posta: ahmetselcukg@gmail.com ORCID: https://orcid.org/0000-0001-6432-6833
\end{abstract}

Doç. Dr. Şevki ULEMA, Sakarya Uygulamalı Bilimler Üniversitesi, Turizm Fakültesi, Sapanca, eposta: ulema@subu.edu.tr

ORCID: https://orcid.org/0000-0002-5874-8797

Öz

Otoimmün bir hastalık olan tip 1 diyabette vücut, pankreasta bulunan beta hücrelerine yabancı bir madde dokunmuş gibi algılayıp saldırarak bu beta hücrelerini yok eder. Sonuç olarak böyle bir durumda vücutta insülin eksikliği ortaya çıkar ve kan şekeri normalin çok üzerinde seviyelere ulaşır. Yani tip 1 diyabetli bireyler insülin üretememektedirler ya da çok az üretebilmektedirler. Böyle olunca dışarıdan insülin takviyesi almak zorundadırlar. Tedavisi; ömür boyu insülin kullanmakla birlikte gerçekleştirilmesi gereken bir diyet programıdır. Dolayısıyla günlük özel bir beslenme gerektirmektedir. Bu nedenle tip 1 diyabetli bireylerin evlerinin dişında bir yiyecek içecek işletmesinde yemek yeme davranışları ile ilgili farklı beklentileri söz konusu olmaktadır. $\mathrm{Bu}$ bağlamda çalışmanın amacı, tip 1 diyabetli bireylerin yiyecek içecek işletmelerinden beklentilerini ortaya koymaktır. Çalışma kapsamında; yarı yapılandırılmış görüşme tekniği kullanılarak 20 tip 1 diyabetli birey ile yüz yüze görüşmeler gerçekleştirilmiştir. Araştırma bulgularına göre; tip 1 diyabetli bireylerin bir yiyecek içecek işletmesinde yemek yeme konusunda en çok karşılaştıkları problemler; fiyat yüksekliği ve menü yetersizliği olarak belirlenmiştir. Yiyecek içecek işletmelerinin menü fiyatlarını yükseltmeyecek şekilde menülerinde küçük değişikliklerde bulunması, tip 1 diyabetli bireylerin memnuniyet düzeyini arttıracaktır.

Anahtar Kelimeler: Tip 1 Diyabet, Yiyecek İçecek İşletmeleri, Tüketici Beklentileri.

Makale Gönderme Tarihi: 18.07.2020

Makale Kabul Tarihi: 07.10.2020

\section{Önerilen Atıf:}

Gürkan, A. S. ve Ulema, Ş. (2020). Tip 1 Diyabetli Bireylerin Yiyecek İçecek İşletmelerinden Beklentileri Üzerine Bir Araştırma, Türk Turizm Araştırmaları Dergisi, 4(4): 3754-3768.

(C) 2020 Türk Turizm Araştırmaları Dergisi. 


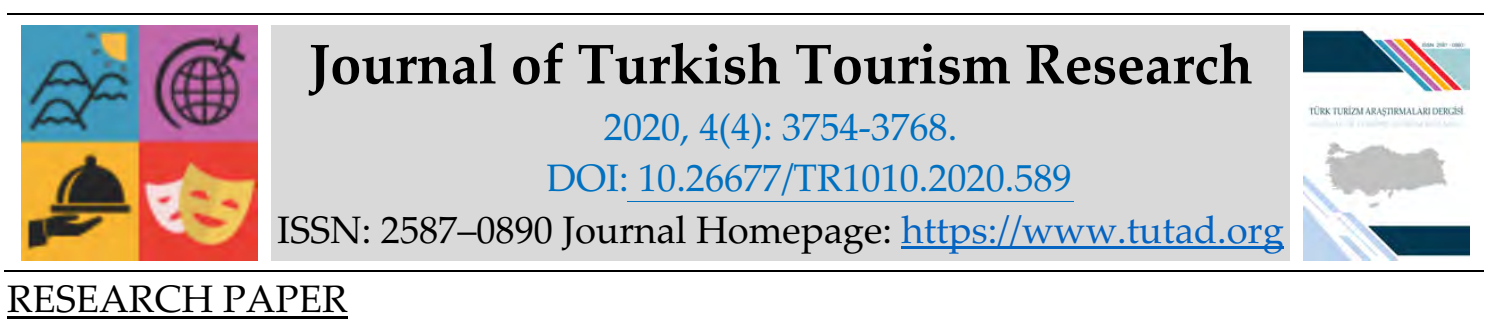

\title{
A Study on the Expectations of Individuals with Type 1 Diabetes from Food and Beverage Companies
}

Ahmet Selçuk GÜRKAN, Ph.D. Student, Sakarya University of Applied Sciences, Faculty of Tourism, Sapanca, e-mail: ahmetselcukg@gmail.com

ORCID: https://orcid.org/0000-0001-6432-6833

Associate Prof. Dr. Şevki ULEMA, Student, Sakarya University of Applied Sciences, Faculty of Tourism, Sapanca, e-mail: ullema@subu.edu.tr

ORCID: https://orcid.org/0000-0002-5874-8797

\begin{abstract}
In type 1 diabetes, an autoimmune disease, the body perceives and attacks the beta cells in the pancreas as if they were touched by a foreign substance, destroying these beta cells. As a result, a lack of insulin occurs in the body and blood sugar reaches levels far above normal. In other words, individuals with type 1 diabetes are unable to produce insulin or are able to produce very little. When this happens, they have to take insulin supplements from outside. The treatment is a diet program that should be performed with the use of insulin throughout life. Therefore, it requires a special daily diet. For this reason, people with type 1 diabetes have different expectations about eating behaviors in a food and beverage business outside their homes. In this context, the aim of the study is to establish the expectations of individuals with type 1 diabetes from food and beverage businesses. In the scope of the study, face-to-face interviews were conducted with 20 Type 1 diabetes patients using the semi-structured interview technique. According to research findings, people with type 1 diabetes have the most problems with eating in a food and beverage business; price height and menu deficiency are determined as. Small changes in the menus of food and beverage companies in such a way as not to increase the menu prices will increase the satisfaction level of individuals with type 1 diabetes.
\end{abstract}

Keywords: Type 1 Diabetes, Food and Beverage Companies, Consumer Expectations.

Received: 18.07 .2020

Accepted: 07.10.2020

\section{Suggested Citation:}

Gürkan, A. S. and Ulema, Ş. (2020). A Study on the Expectations of Individuals with Type 1 Diabetes from Food and Beverage Companies, Journal of Turkish Tourism Research, 4(4): 3754-3768. (C) 2020 Türk Turizm Araştırmaları Dergisi. 


\section{Gíriş}

Hayatın devam ettirilmesinde beslenme temel bir gereksinimdir. İnsanın yaşamı süresince bu olgunun bireyin yaşam kalitesini de belirlediği söylenebilir. Beslenme, insanın büyümesi, gelişmesi, fizyolojik işlevlerini sürdürebilmesi için gerekli olan öğelerin vücuda alınıp kullanılması olarak tanımlanır (Kocatepe ve Turan, 2012: 46).

Beslenme, sağlığı çok yakından ilgilendirmektedir. Eksik ya da yanlış beslenme alışkanlıkları obezite, kalp-damar hastalıkları, hipertansiyon, kanser ve diyabet gibi hastalıklara yakalanma riskini artırmaktadır. Bu hastalıklardan korunmak, uzun ve sağlıklı bir yaşam şansını artırmak için mutlaka yeterli ve dengeli beslenmeye önem verilmelidir (Sayan, 1993: 53).

Her insanın farklı özelliklerde olması beslenme ihtiyacının giderilmesinde de ortaya çıkmaktadır. Bireye özgü sağlık sorunları ve gıda alerjileri gibi durumlar bireyin beslenme düzenini de etkilemektedir. Beslenme ile ilgili bireyin dikkat etmesi gereken özel durumlar (sık ve aralıklarla yemek yeme, belirli ürünlerin tüketilmemesi vb.) evde yemek yeme düzeninde kolayca çözümlenebilmekte iken, dışarıda yemek yeme ihtiyacı ortaya çıktığında durum farklılık göstermektedir. Çünkü dışarıda aranan özellikte yiyeceklerin kolayca bulunması ya da bulunan yiyeceklerin sağlıklı ve istenilen niteliklerde olup olmaması ile ilgili sorunların mutlaka aşılması gerekmektedir. $\mathrm{Bu}$ durum bir istekten daha çok sağlıklı beslenmeden kaynaklanan bir gerekliliktir. Bu karşılanmadığında ise beslenme ile ilgili özel gereksinimi olan bireyler zehirlenme, sağlığın bozulması, komaya girme ve ölüm gibi istenmeyen birtakım sorunlarla karşı karşıya kalabilmektedir (Güçlü Nergiz, 2017: 125-126).

Türü ve niteliği ne olursa olsun yiyecek içecek işletmelerinin, hizmet verdikleri kişilerin sağlıklarına yönelik direkt hizmet verdikleri unutulmamalıdır. Yiyecek içecek işletmelerinin kar amaçlı bir anlayıştan ziyade, insan sağlığına önem veren bir anlayışı benimsiyor olmaları gerekmektedir (Demirkol, 2015: 163).

Bu bağlamda çalışmada; tip 1 diyabetli bireylerin yiyecek içecek işletmelerinden beklentilerini belirlemek ve bu işletmelerde karşılaştıkları sorunları ölçmek amaçlanmıştır. Bu sorunların bir farkındalık oluşturacağı öngörülmektedir. Bu amaçla ilk olarak diyabet kavramı, özellikleri ve çeşitleri üzerinde durulmuştur. Sonrasında tip 1 diyabet ve beslenme arasındaki ilişkiden bahsedilmiştir. Son olarak çalışma kapsamında tip 1 diyabetli bireylerin yiyecek içecek işletmelerinden beklentileriyle alakalı durum tespiti yapılmıştır.

\section{LITERATÜR TARAMASI}

\section{Diyabet ve Çeşitleri}

İnsülin, kandaki şeker oranını dengeleyen hormondur. İnsülin hormonunun eksikliği ya da pankreastan yeterince salgılanmaması sonucunda kronik metabolizma bozukluğu oluşur. Bu metabolik bozukluğa diyabet denilmektedir. Halk arasında 'şeker hastalığı' olarak bilinen diyabetin tıptaki karşılığı 'diabetes mellitus' olarak geçmektedir. Normal değeri 70-100 mg/dl olan ve minimum 8 saat aç kaldıktan sonra ölçülen kan şekeri seviyesine 'açlık kan şekeri' denir. 'Tokluk kan şekeri' ise yemeğe başlanılan süreden 2 saat sonra ölçülen ve normal değeri 70-140 $\mathrm{mg} / \mathrm{dl}$ olan kan şekeri seviyesidir (www.hsgm.saglik.gov.tr). 
Tablo 1. Dünya'da Diyabetli Birey Sayısı (2019)

\begin{tabular}{|l|l|l|}
\hline \multicolumn{2}{|l|}{ Nüfus } & Diyabetli Nüfusu \\
\hline $\begin{array}{l}\text { Yetişkin Nüfus } \\
\text { (20-79 Yaş) }\end{array}$ & 5.0 Milyar & 461.88 Milyon \\
\hline $\begin{array}{l}\text { Çocuk Nüfus } \\
\text { (0-19 Yaş) }\end{array}$ & 2.58 Milyar & 1.11 Milyon \\
\hline Toplam & 7.7 Milyar & 463 Milyon \\
\hline
\end{tabular}

Kaynak: (www.idf.org).

Tablo 1'de 2019 yılı itibariyle Dünya'da diyabetli sayıları verilmiştir. Tabloya göre toplamda 463 milyon diyabetli birey bulunmaktadır. T.C. Sağlık Bakanlığının en son yayınladığı 2015 'Sağlık.NET' verilerine göre ise, Türkiye'de 7.112.000 diyabetli birey bulunmaktadır. Ayrıca Uluslararası Diyabet Federasyonu ve T. C. Sağlık Bakanlığı diyabetli birey sayısı paylaşımlarında tip 1 diyabetli birey sayılarını ayrı olarak belirtmemişleredir.

Diyabet çeşitleri ise şunlardır (www.diabetcemiyeti.org, 2020; www. hsgm.saglik.gov.tr, 2020);

- Tip 1 Diyabet

- $\quad$ Tip 2 Diyabet

- Tek Gen Hastalığına Bağlı Diyabet

- Gestasyonel Diyabeti (Gebelik Diyabeti)

- Diğer Tipler

Diyabet çeşitleri tip 1 diyabet, tip 2 diyabet, tek gen hastalığına bağlı diyabet, gestasyonel diyabet ve diğer tipler olarak beş gruba ayrılmasına rağmen yaygın olarak literatürde tip 1 diyabet ve tip 2 diyabet olarak bahsedilmektedir.

Tablo 2. Tip 1 ve Tip 2 Diyabet Arasındaki Farklar

\begin{tabular}{|l|l|}
\hline Tip 1 Diyabet & Tip 2 Diyabet \\
\hline Genellikle çocuk ve ergenlerde görülür. & $\begin{array}{l}\text { Genellikle ileri yaşlarda görülür. } \\
\text { Son yıllarda çocuk ve ergenlerde obezite ile } \\
\text { görülmektedir (en sı ergenlik dönemi } \\
\text { sonrası). }\end{array}$ \\
\hline Genellikler zayıf ya da normal kilodadırlar. & Genellikle obezdirler. \\
\hline $\begin{array}{l}\text { İnülin üretimi olmadı̆̆ için insülin } \\
\text { kullanmak zorundadırlar. }\end{array}$ & $\begin{array}{l}\text { Genellikle ilaç kullanırlar ancak bazı özel } \\
\text { durumlarda insülin de kullanırlar. }\end{array}$ \\
\hline
\end{tabular}

Kaynak: (www.hsgm.saglik.gov.tr). 
Genel olarak erken yaşlarda ortaya çıkan ve tanı konulmasından itibaren sadece insülin tedavisi gerektiren diyabet türüne tip 1 diyabet adı verilmektedir. Öyküsünde sağlıksız beslenme, fiziksel aktivite eksikliği, sağlıksız yaşam biçimi davranışları bulunan ve daha ileri yaşlarda ortaya çıkan diyabet türüne ise tip 2 diyabet adı verilmektedir. Tip 2 diyabette genellikle sadece kan şekeri düzenleyici ilaçlar ile kan şekeri düzenlenmeye çalışılır. Kan şekeri seviyesi ilaçlarla uygun seviyelere ulaşamadığ durumlarda geçici bir süreliğine insülin tedavisi tip 2 diyabetli bireyler içinde uygulanabilir (www.hsgm.saglik.gov.tr).

Tip 2 diyabette pankreastan insülin salgısı yetersizdir ve insülin direnci vardır. Bu nedenle tedavisinde ilerleyen dönemler haricinde insülin gerekmez. Genelde kan şekeri düzenleyici ilaçların yanında egzersiz ve beslenme programlarıyla tedavi edilebilir. En sık görülen diyabet türü tip 2 diyabet olup tüm diyabetlilerin içinde oranların \%90-95'ini oluşturmaktadır (www.diabetcemiyeti.org).

Tip 1 diyabetli bireyler ise kan şekeri seviyelerini uygun aralıkta tutmak için insülin enjeksiyonuna ihtiyaç duymaktadırlar. Vücutlarına dışarıdan insülin almadan kan şekerini kontrol altına almamaktadırlar. Kısaca insülin kullanmadan hayatta kalmaları mümkün değildir (www.idf.org).

Tip 1 diyabetli bireylerin kan şekeri düzeylerini normal seviyede tutmaları, ögü̈nlerinde kullandıkları insülin dozları ve besin değerlerine (örn. karbonhidrat) göre değişkenlik göstermektedir (Özbek, 2018: 48). Bu durum tip 1 diyabetli bireylerin hayatlarında beslenme alışkanlıklarının önemini ortaya koymaktadır.

\section{Tip 1 Diyabet ve Beslenme}

İnsan vücudunun çalışması için gereken besin ögelerinin vücuda alınıp, sindiriminin, emiliminin ve metabolize olmasının sağlanmasına beslenme denir. Dengeli beslenme ise vücudun gereksinim duyduğu besin öğelerinin (karbonhidrat, protein, yağ, vitamin ve mineraller) dengeli ve yeterli miktarda alınmasıdır (Ersoy, 2004: 14).

Tip 1 diyabetli bireylerde iyi bir beslenme düzeni oluşturmak, yeterli ve dengeli beslenme düzenini sağlamak amaciyla oldukça önemlidir. Diğer bir amaç ise diyabet sebebiyle oluşması muhtemel komplikasyonların önüne geçmek için mümkün olan en iyi glisemik kontrolü sağlamaktır. Bu yüzden tip 1 diyabetli bireyleri yaşam boyu sağlıklı beslenme alışkanlıklarına teşvik etmek büyük bir önem taşımaktadır (Gillepie, 1998: 898; Altınok, 2018: 36).

Tip 1 diyabette ne yiyeceğini bilmek, tip 1 diyabetli bireyler için genelde zor olmaktadır. Kan şekeri düzeyini korumak için yiyecekleri, insülin dozlarını ve fiziksel aktiviteyi dengelemek amacıyla tip 1 diyabetli bireylerin iyi bir stratejiye ihtiyaçları vardır. Tip 1 diyabette farklı yiyeceklerin kan şekerini nasıl etkilediğini öğrenmek ve günlük rutinlerinde bunu nasıl dengeleyeceğini bulmak çok önemlidir. Tip 1 diyabetli bireyler için bu dengeyi bulmak biraz deneme yanılma gerektirir (www.diabetes.org).

Tip 1 diyabette farklı gıdaların kan şekeri düzeyini farklı şekillerde etkilemesinden dolayı sağlıklı beslenme diyabet yönetiminin önemli bir parçasıdır. Sadece tip 1 diyabetli bireyler için değil diyabetli tüm bireyler için sağlıklı bir beslenme programında, aşırı kiloluysanız kalori miktarını azaltmayı, doymuş yağları (örn. krem, peynir, tereyağı) doymamış yağlarla (örn. avokado, fındık, zeytin ve sebze yağları) değiştirmeyi, diyet lifi yemeyi içerir (örn. meyve, sebze, tam tahıllar). Bunun yanında şekerli besinlerden, alkol ve tütün kullanımından kaçınmak gerekmektedir. (www.idf.org). 
Son yıllarda tip 1 diyabet tedavisi için düşük karbonhidratlı diyetler, sosyal medya kullanıcıları tarafından popüler hale getirilmiştir. Özellikle karbonhidrat sayımı yöntemi uygulamalarının yaygınlaşması, beraberinde tip 1 diyabetli bireyler arasında düşük karbonhidratlı besin tüketimi eğilimini artırmıştır. Düşük karbonhidratlı diyetler aynı zamanda bireylerin kilo kontrolü için de moda haline gelmiştir. Popüler dergi, kitap, televizyon ve kişisel sosyal medya hesapları gibi ortamlarda düşük karbonhidratlı diyetler "sağlıklı" olarak yansıtılmaktadır. Genel olarak, bu tür paylaşımlar, tip 1 diyabetli bireylerde daha az insülinin daha iyi olduğu fikrini yaygınlaştırmıştır. Halbuki tip 1 diyabetli çocuklarda ve yetişkinlerde karbonhidrat kısıtlaması, düşük enerji alımı sonucu büyüme hızında azalmaya ve yüksek riskli hastalıklara zemin hazırlayabilir (Smart vd., 2018: 137). Bunun yanı sıra düşük karbonhidrat alımı hipoglisemi (kan şekeri düşmesi) riskini artırabilir veya glukagonun hipoglisemi tedavisindeki etkisine potansiyel olarak zarar verebilir (Ranjan vd., 2017: 133). Bu doğrultuda Tip 1 diyabetli bireylerde bu tarz beslenme uygulamaları ve sürekliliğinin sağlanması güçtür. Tip 1 diyabetli bireylere kan şekeri regülasyonunu sağlama ve sağlıklı öğün planlaması yapmaları için karbonhidrat sayımı yöntemini uygulamaları önerilmektedir (Zipp vd., 2011: 7).

\section{Tip 1 Diyabetli Bireylerin Besin Tüketiminde Karbonhidrat Sayımı Yöntemi}

Karbonhidratlar, kan şekerini direkt olarak etkileyen besin öğesidir (Telek, 2017: 5). Karbonhidrat sayımı yöntemi ise, tip 1 diyabetli bireylerin beslenme tedavilerine yönelik bir yaklaşım şeklidir (Koyunoğlu Bingöl, 2013: 34).

Karbonhidrat sayımı yönteminde amaç, tip 1 diyabetli bireylerin öğünlerinde tükettikleri karbonhidrat miktarı ve fiziksel aktiviteye göre insülin dozunu ayarlayarak kandaki şeker kontrolünü sağlamaktır. Karbonhidrat sayımı yöntemi, öğün öncesi ve öğün sonrası kan şekeri değerlerinin ölçülmesi, buna bağlı olarak ögündeki karbonhidrat miktarının belirlenip hedef kan şekeri değerine ulaşmak için ihtiyaç duyulan insülin dozunun hesaplanmasıyla yönetilir (Mahan vd., 2012: 677).

Karbonhidrat sayımı yöntemi, tip 1 diyabetli bireylerin ana ve ara ögünlerde tükettikleri yiyecek ve içeceklerin içinde bulunan karbonhidrat miktarının bilinip, tüketilecek karbonhidrat oranına göre insülin dozunun hesaplanmasına dayanır. Bu yöntem sayesinde tip 1 diyabetli bir birey, kan şekeri değeri normal değerlerin altında ya da üzerinde olduğu durumlarda kan şekeri düzeyine göre, öğünlerinde tüketeceği karbonhidrat miktarıyla birlikte insülin dozunu arttırabilir ya da azaltabilir. Karbonhidrat/insülin oranı kişiden kişiye değişiklik gösterebilir (Özer, 2013: 25).

Günümüzde beslenme alışkanlıkları genelde ev dışında besin tüketimine yöneliktir. Ev dışında besin tüketimi artık sıklıkla karşılaşlan bir durumdur. İnsanlar her ortamda besin seçme esnekliklerine ve özgürlüklerine sahiptirler. Her ortamda besin seçme esnekliği ve özgürlügünün sağlanabilmesi tip 1 diyabetli bireyler içinde oldukça önemlidir (Rabasa-Lhoret, 1999: 670). Karbonhidrat sayımı yöntemi sayesinde tip 1 diyabetli bireyler besin seçiminde esneklik sağlayabilirler (Gökşen vd., 2014: 75). Ancak bu esnekliğin sağlanabilmesi için yiyecek porsiyonlarının kesin olarak bilinmesi gerekmektedir (Sheard vd., 2004: 2268). Bu bağlamda besin değerlerinin bir yiyecek içecek işletmesi menüsünde belirtilmesi tip 1 diyabetli bireylerin yiyecek içecek işletmelerinde besin seçimlerinde esneklik sağlayabilir. Bu da tip 1 diyabetli bireylerin yiyecek içecek işletmelerinde yemek yeme sıklıklarını arttırabilir. Dolayısıyla bu durum tip 1 diyabetli bireylere daha iyi bir yaşam kalitesi sunacaktır. 


\section{YÖNTEM}

\section{Araştırmanın Amacı ve Önemi}

$\mathrm{Bu}$ çalışmanın temel amacı, tip 1 diyabetli bireylerin dışarıda yemek yeme konusunda karşılaştıkları sorunları ve yiyecek içecek işletmelerinden beklentilerini ortaya koymaktır. Tip 1 diyabetli bireylerin yiyecek içecek işletmelerinde yemek yeme konusunda karşılaştıkları problemlerin giderilmesine yönelik çözüm önerilerinin sunulması da bu araştırmanın bir diğer amacıdır. Yiyecek içecek işletmelerinin tip 1 diyabetli bireylerin beklentilerine göre daha kaliteli hizmet sunabilmesi ve karşılaşılan sorunların azaltılması araştırmanın önemini ortaya koymaktadır. İlgili literatürde tip 1 diyabetli bireylerin yiyecek içecek işletmelerinden beklentileriyle alakalı bir çalışmanın bugüne kadar yapılmış olmaması araştırmanın bir diğer önemini ortaya koymaktadır.

\section{Araștırmanın Evreni ve Örneklemi}

Araştırmanın evrenini, Türkiye'de yaşayan tanı konulmuş tip 1 diyabetli bireyler oluşturmaktadır. Çalışma kapsamında Türkiye'nin çeşitli illerinde yaşayan 20 tip 1 diyabetli bireye, olasılığa dayalı olmayan örnekleme yöntemlerinden amaçlı örnekleme yöntemi kullanılarak ulaşılmıştır.

\section{Veri Toplama Tekniği}

$\mathrm{Bu}$ araştırmada nitel araştırma yöntemlerinden yarı yapılandırılmış görüşme tekniğine başvurulmuştur. Nitel çalışmalarda, bilginin kime yarar sağladığı kadar araştırmacının; araştırma konusuyla ve araştırma katılımcılarıyla olan ilişkisi gibi etmenler de oldukça önemlidir (Alvesson vd., 2008: 480; Patton, 1999: 1198). Bu bağlamda çalışmada araştırmacı, katılımcılarla sosyal hayatta etkileşim içindedir ve bu kişilerle benzer deneyimler yaşamaktadır.

Araştırma kapsamında 20 tip 1 diyabetli birey ile, online olarak kamera karşısında yüz yüze görüşmeler gerçekleştirilmiştir. Katılımcılara doğrudan 6 soru yöneltilip, aynı zamanda konu ile ilgili kendi fikirlerini ekleyebilecekleri ve cevapları genişletebilecekleri serbestlik sağlanmıştır. Araştırma amaçları doğrultusunda hazırlanan yarı yapılandırılmış görüşme formu, belirlenen katılımcılara, müsaitlik durumları göz önünde bulundurularak önceden gün ve saat bildirilerek 1 Mayıs ve 1 Haziran 2020 tarihleri arasında gerçekleştirilmiştir. Görüşmeler yaklaşık olarak 30 dakika sürmüştür.

Katılımcılara yöneltilen 6 soru ile katılımcıların ne sıklıkla bir yiyecek içecek işletmesinde yemek yediği, gidecekleri yiyecek içecek işletmesinin menüsünün kendileri için uygunluğu, bulundukları şehirdeki yiyecek içecek işletmelerinden memnuniyet düzeyleri ve gelişimi için yapılabilecekler konusundaki önerileri ile yiyecek içecek işletmelerinden beklentilerinin ölçülmesi hedeflenmiştir.

Katılımcılara yöneltilecek sorular Tozlu Özhan (2018)'ın 'Turizme Katılımda Engelli Bireylerin Motivasyon ve Beklentilerine İlişkin Görgül Bir Araştırma" adlı çalışmasından uyarlanmıştır. Bu sorular aşağıda yer almaktadır;

- Ne sıklıkla bir yiyecek içecek işletmesinde yemek yersiniz?

- Gideceğiniz yiyecek içecek işletmesinde size uygun bir menü olup olmadığını sorguluyor musunuz?

- Tip 1 diyabetli bir birey olarak, bir yiyecek içecek işletmesinde sizce menü nasıl olmalı ve nelerden oluşmalı? 
- Tip 1 diyabetli bir birey için yiyecek içecek işletmelerinde harcanılan bütçe sizce farklılık gösteriyor mu?

- Sürekli gittiğiniz bir yiyecek içecek işletmesi var mı? Her zamanki yiyecek içecek işletmesi rotanızı değiştirmeyi tercih etmenize sebep olacak şeyler nelerdir?

- Tip 1 diyabetli bir birey olarak sizin için farklı yiyecek içecek kültürlerini keşfetmek, yöresel yemekleri tatmak gibi durumların önemi nedir?

\section{BULGULAR}

Bu bölümde, katılımcıların demografik özelliklerine yönelik bulgular belirtilip katılımcıların yiyecek içecek işletmelerinden beklentilerine yönelik unsurlar, görüşme soruları çerçevesinde alınan yanıtların ortak noktalarının düzenlenmiş hali ile sunulmuştur.

Katılımcıların cinsiyetlerine bakıldığında 9 katılımcı kadın, 11 katılımcı ise erkektir. Katılımcların yaşlarına bakıldığında, 2 katılımcının 19 yaşında, 9 katılımcının 20-29 yaş aralığında, 9 katılımcının 30-39 yaş aralığındadır. Katılımcıların eğitim durumlarına bakıldığında 4 katılımcı lisans öğrencisi, 15 katılımcı lisans mezunu, 1 katılımcı ise lisansüstü mezunu olduğunu belirtmiştir. Evli olan katılımcı sayısı 7, bekar olan katılımcı sayısı ise 13'tür. Katılımcıların aylık gelir durumları değerlendirildiğinde orta gelir grubuna dahil oldukları söylenebilir.

\section{Katılımcıların Bir Yiyecek İçecek İşletmesinde Tüketim Sergileme Sıklıkları Üzerine Bulgular}

Katılımcıların yiyecek içecek işletmelerinde ne sıklıkla yemek yedikleri değerlendirildiğinde tüm katılımcılar ayda ortalama üç defa dışarıda yemek yediklerini belirtmiştir. Bu görüşme sorusu altında katılımcılara konu ile ilgili sağlanan serbestlik sonucunda, Türkiye'nin üç büyük şehrinde yaşadığını belirten katılımcıların dışarıda yemek yeme alışkanlıklarının diğer şehirlerde yaşayan katılımclara göre daha yüksek olduğu görüşmeler sonucunda anlaşılmıştır. Bu kişilerin genellikle diyet menü içeren yiyecek içecek işletmelerini tercih ettikleri belirlenmiştir. Bu bağlamda, küçük şehirlerde diyet menü içeren yiyecek içecek işletmelerinin bulunmaması ya da az sayıda bulunmasından bu sonuca ulaşıldığı öngörülmektedir. Bu katılımcların ayrıca, daha çok sosyalleşmek amaciyla akşam yemeklerini bir yiyecek içecek işletmesinde yemeyi tercih ettikleri belirlenmiştir.

Daha küçük şehirlerde yaşadıklarını belirten katılımcılar ise mecbur kaldıklarında (örn. kan şekeri düşmesi, dışarıda vakit geçirme/çalışma zorunluluğu) veya nadiren sosyalleşmek (örn. özel günler, arkadaş ya da aile bireyleriyle vakit geçirmek) amacıyla bir yiyecek içecek işletmesinde yemek yediklerini belirtmişlerdir. Bu görüşme sorusu başlığı altında bu sebepler dışında bir yiyecek içecek işletmesinde keyfi yemek yememe nedenleri aynı katılımcılara sorulduğunda, diyet menüden ziyade glisemik indeksi düşük karbonhidratların yiyecek içecek işletmelerinde yer almamasının katılımcılar için problem teşkil ettiği anlaşılmıştır. Katılımcıların verdiği cevaplar doğrultusunda ayran ve şalgam gibi düşük karbonhidratlı içecekler dışında şekersiz diyet içeceklerin yiyecek içecek işletmelerinde menülerde yer almaması da zaten çok seyrek dışarıda yiyecek içecek tükettiğini belirten katılımcıların dışarıda yemek yeme motivasyonlarını etkilediği sonucuna ulaşılmıştır. Dolayısıyla çalışma kapsamında, daha küçük şehirlerde bulunan yiyecek içecek işletmelerinde glisemik indeksi düşük karbonhidratların ve diyet içeceklerin hiç bulunmadığı ya da çok nadir bulunduğu belirlenmiştir. Yiyecek içecek 
işletmelerinin bu ürünlere menülerinde yer vermeleri tip 1 diyabetli bireylerin dışarda yemek yeme alışkanlıklarını arttırabilir.

\section{Katılımcıların Bir Yiyecek İçecek İşletmesinde Menü İçeriğini Sorgulamalarına Dair Bulgular}

Katılımcların yiyecek içecek işletmelerinde kendilerine uygun bir menü olup olmadığını sorgulamaları değerlendirildiğinde lisans öğrencisi olduğunu belirten katılımcılar dışındaki diğer katılımcılar kendilerine uygun bir menü olup olmadığını sorguladıklarını belirtmişlerdir. $\mathrm{Bu}$ görüşme sorusu altında katılımcilara konu ile ilgili sağlanan serbestlik sonucunda, büyük şehirlerde yaşayan katılımcıların bir yiyecek içecek işletmesinde kendilerine uygun menü olup olmadığını genellikle telefon uygulamaları aracılı̆̆ıyla araştırdıkları anlaşılmıştır. Ayrıca bu katılımcılar, tüketecekleri ürünlerin fiyatlandırmalarında da herhangi bir sürprizle karşılaşmamak adına bu uygulamaları kullandıklarını belirtmişlerdir.

Lisans öğrencisi olduğunu belirten katılımcılar ise bir menüde kendilerine uygun yiyecek mutlaka bulduklarını, onlar için diyet içeceklerin menüde bulunup bulunmamasının daha çok önem teşkil ettiği, bunu da yiyecek içecek işletmesine gitmeden önce sorgulamadıklarını belirtmiş̧lerdir. Dolayısıyla lisans öğrencileri ve yetişkin bireylerin tip 1 diyabet yönetiminde farklı düşüncelere sahip olduğu bu görüşme sorusu kapsamında verilen cevaplardan anlaşılmıştır. $\mathrm{Bu}$ durumun demografik farklılıklarla birlikte maddiyatla ilgili olduğu da öngörülmektedir.

\section{Katılımcıların Bir Yiyecek İçecek İşletmesi Menüsünden Beklentileri Üzerine Bulgular}

Katılımcıların bir yiyecek içecek işletmesi menüsünden beklentileri üzerine elde edilen bulgular kapsamında büyük şehirlerde yaşadığını belirtip diyet menü içeren yiyecek içecek işletmelerini tercih eden katılımclların bir yiyecek içecek işletmesi menüsünden beklentileri değerlendirildiğinde, bu katılımcıların menüde üzerinde durduğu konunun doğru bilgilendirme olduğu anlaşılmıştır. Katılımcıların hepsi karbonhidrat sayımı yöntemiyle insülin dozlarını ayarladıklarını, dolayısıyla menüde karbonhidrat miktarının yanlış belirtilmesinin kan şekeri düşmesine ya da kan şekeri yükselmesine neden olacağını belirtmiş̧lerdir. Bu katılımcılar genel olarak menü içeriklerinden memnun olduklarını söylemişlerdir. Menü içeriğinden memnun olmadıkları yiyecek içecek işletmelerine ise zaten gitmedikleri bu görüşme sorusuna verilen cevaplardan anlaşılmıştır. Dolayısıyla tip 1 diyabetli bireylerin yiyecek içecek işletmelerinde herhangi bir sağlık sorunu yaşamamaları adına menü içeriği mutlaka doğru bir şekilde verilmelidir.

Küçük şehirlerde yaşadığını belirten katılımcıların üzerinde durduğu konu ise daha çok glisemik indeksi düşük karbonhidratların ve diyet içeceklerin menülerde yer almamasıdır. Bu görüşme sorusu altında elde edilen bulgulara göre, beklentilerini karşılayabilecek düzeyde menüye sahip olan yiyecek içecek işletmelerinin sayıca çok az olduğunu belirten katılımcılar, bu işletmelerin menülerinin pahalılığından dolayı tercih etmediklerini belirtmişlerdir. Bu katılımcılar için iyi bir menü glisemik indeksi düşük karbonhidratlar ve diyet içecekler içermelidir. Katılımcılar ayrıca porsiyonlarda karbonhidratların yanında sebze ve süt grubu ürünlerin bulunması gerektiğini de vurgulamışlardır.

Bu görüşme sorusu altında katılımcllara konu ile ilgili sağlanan serbestlik sonucunda, menüde sunulan yiyecek ve içecekler hakkında yiyecek içecek işletmesi çalışanlarının yeterli düzeyde 
bilgi sahibi olmamaları, katılımcı tip 1 diyabetli bireylerin çeşitli sorunlarla karşılaşmalarına neden olduğu sonucuna ulaşılmıştır. Dolayısıyla yiyecek içecek işletmeleri, menü içeriklerini doğru bilgilendirmeleri gerektikleri kadar çalışanlarına da işletmede sunulan yiyecek ve içecekler hakkında eğitim vermelidir.

\section{Katılımcıların Bir Yiyecek İçecek İşletmesinde Harcadıkları Bütçe Üzerine Düşünceleri}

Katılımcılara göre bir yiyecek içecek işletmesinde harcanılan bütçenin diğer bireylere göre farklılık gösterip göstermediği değerlendirildiğinde tüm katılımcılar, kendilerine uygun menü içeren yiyecek içecek işletmelerinin fiyatlarının yüksek olması nedeniyle bütçenin kesinlikle farklılık gösterdiğini belirtmişlerdir. Bu görüşme sorusu altında katılımcılara konu ile ilgili sağlanan serbestlik sonucunda, fiyatların yüksek olması yanında, bu fiyatlara göre beklentilerin karşılanamaması da katılımcıların bir yiyecek içecek işletmesinde tüketim gösterme motivasyonlarını olumsuz yönde etkilediği anlaşılmıştır. Katılımcıların bir kısmı, günlük hayatlarında tükettikleri glisemik indeksi düşük karbonhidratları (yulaf içeren ekmekler) daha uygun bütçeli bir yiyecek içecek işletmesine giderken yanlarında götürdüklerini, dolayısıyla diğer yüksek fiyatlı menü içeren yiyecek içecek işletmelerine daha fazla ücret ödememek adına böyle çözümler üretmeye çalıştıklarını belirtmişlerdir. Dolayısıyla bu durum katılımcıların bir yiyecek içecek işletmesinde bağımsız davranmalarını engellemektedir.

$\mathrm{Bu}$ görüşme sorusu kapsamında elde edilen bulgulara göre katılımcılar açısından bir yiyecek içecek işletmesinden beklentilerin karşılanmış olması veya olmaması durumu, tüketicilerin ürün ya da hizmetler için yaptıkları parasal harcamalarına karşılık görecekleri değer açısından önem taşımaktadır. Menü fiyatlarının yüksek olmasıyla alınan hizmetin paralellik göstermemesi tip 1 diyabetli bireylerin dışarıda yemek yeme motivasyonlarını olumsuz yönde etkilemektedir. Dolayısıyla yiyecek içecek işletmelerinin hizmet kalitelerini arttırıp menü fiyatlarını normalleştirmeleri gerekmektedir.

\section{Katılımcıların Yiyecek İçecek İşletmelerini Çeşitlendirmelerine Sebep Olacak Etkenler}

Katılımcıların her zaman gittikleri yiyecek içecek işletmelerini değiştirmelerine neden olacak faktörler değerlendirildiğinde tüm katılımcıların bahsettiği ortak noktaların erişilebilirlik ve erişilebilirliğe bağlı olarak normal bir fiyatlandırma olduğu bu görüşme sorusuna verilen cevaplardan anlaşılmıştır. Katılımcıların tümünün sürekli gittiği bir yiyecek içecek işletmesi vardır. Ancak bu süreklilik, erişilebilirliğin kısıtlı olmasından kaynaklıdır. Yiyecek içecek işletmelerine yönelik tip 1 diyabetli katılımcıların görüşlerine bakıldığında erişilebilirlik kadar, yiyecek içeceklerin hijyen koşullarına uygun bir şekilde üretilmesinin de büyük önem taşıdığ anlaşılmaktadır.

$\mathrm{Bu}$ bağlamda katılımcılarla yapılan görüşme sonucunda katılımcıların, her zaman gittikleri yiyecek içecek işletmelerinden erişilebilirlik, uygun fiyatlandırma ve hijyen şartları sağlayan başka bir yiyecek içecek işletmesi olması takdirde tercihlerinde değişiklik olabileceği anlaşılmıştır. Dolayısıyla yiyecek içecek işletmelerinin menülerine glisemik indeksi düşük karbonhidratlar ve diyet içecekler eklemesinin yanında menülerinde gerekli fiyat düzenlemelerinin yapılması ve hijyen koşullarının sağlanması tip 1 diyabetli bireylerin sürekli gittikleri yiyecek içecek işletmelerinin çeşitlenmesine neden olacaktır. 


\section{Katılımcıların Farklı Yiyecek İçecek Kültürlerini Keşfetme İstekleri Üzerine Bulgular}

Katılımcı tip 1 diyabetli bireylerin yiyecek içecek işletmelerinden temel beklentilerinin yanı sıra, tatmak istedikleri farklı yiyecek içecek kültürleri ve yöresel yemeklerin bulunduğu da bu görüşme sorusu sonucunda anlaşılmıştır. Katılımcılar için farklı yiyecek içecek işletmelerini keşfetmek ve yöresel yemekleri tatmak gibi durumlar önemli olsa da daha önce tatmadıkları yiyeceklere insülin dozlarını ayarlamakta yaşadıkları sıkıntılardan dolayı, söz konusu faaliyetleri ancak tatile çıkma, farklı şehir ve ülkelere ziyaretlerde bulunma gibi sebeplerden dolayı nadiren gerçekleştirdikleri anlaşılmıştır.

Katılımcılara konu ile ilgili sağlanan serbestlik sonucunda katılımcılar, özellikle Türkiye'ye ait yöresel yemeklerin çok yağlı olmasının kan şekeri seviyelerinde ciddi yükselmelere neden olduğunu belirtmişlerdir. Katılımcılar, içeriğini bilmeyip tükettikleri bazı yöresel yemeklerden 34 saat sonra ekstra insülin dozu yapmak zorunda kaldıklarını, dolayısıyla yöresel yemek tüketirken daha dikkatli olduklarını belirtmişlerdir. Dolayısıyla menülerinde yöresel ürün bulunduran işletmelerin, yiyecek ve içeceklerin içeriğini menülerine eklemeleri tip 1 diyabetli bireylerin tüketim sergileme davranışlarını etkileyecektir.

Genel olarak bakıldığında katılımcı tip 1 diyabetli bireylerin tümünün beslenmelerinde karbonhidrat sayımı yöntemine başvurdukları görüşme soruları kapsamında verilen cevaplardan anlaşılmıştır. Tip 1 diyabetli bireylerin karbonhidrat sayımı yöntemiyle öğünlerinde insülin dozlarını belirlemeleri, onlara dışarıda yemek yeme konusunda rahatlık sağlamaktadır. Tip 1 diyabetli bireyler literatürde açıklandığı gibi insülin dozlarını ayarlamak için tükettikleri besinlerde doğru karbonhidrat oranını bulabilmek amaciyla deneme-yanılma yoluna başvurmaktadırlar. Ancak bu durum süreklilik arz ettiğinde tip 1 diyabetli bireyler, kan şekerlerinde oluşacak sürekli dalgalanmalar neticesinde ileride sağlık anlamında ciddi problemler yaşayabilirler. Dolayısıyla yiyecek içecek işletmelerinin menülerinde yiyecek ve içeceklerin içeriklerini belirtmeleri tip 1 diyabetli bireylerin kan şekeri düzeyi dalgalanmalarını azaltmalarına neden olacaktır. Bu da tip 1 diyabetli bireylerin hem daha sağlıklı yaşamalarını sağlayacaktır hem de dışarıda yemek yeme alışkanlıklarını olumlu yönde etkileyecektir.

Son olarak çalışma kapsamında yöneltilen tüm sorulara içtenlikle yanıt veren katılımcılar, çalışmanın bireysel fikirlerinin alınması yönünde yapılandırılmış olmasından dolayı memnuniyetlerini belirtmişledir. Ayrıca, çalışmanın uygulamada da etkili olmasına yönelik temennilerini dile getirmişlerdir.

\section{TARTIŞMA, SONUÇ ve ÖNERILLER}

Yapılan görüşmeler sürecinde, tip 1 diyabetli bireylerin yiyecek içecek işletmelerinden beklentilerini belirlemek üzere oluşturulan görüşme soruları ile doğrudan tip 1 diyabetli bireylerin görüşlerinin alınması hedeflemiştir. Görüşmeler sürecinde, tip 1 diyabetli bireylerin yaklaşımları ve söylemleri doğrultusunda çalışmanın kendi fikirleri alınarak yürütülüyor olmasından hoşnut oldukları anlaşılmıştır.

Çalışma kapsamında katılımcıların ayda ortalama üç kez dışarıda yemek yedikleri anlaşılmıştır. Bu rakamın özellikle yoğun çalıştığını belirten tip 1 diyabetli bireyler açısından düşük olduğu söylenebilir. Bu sonucun deneyim ile ilişkili olduğu çalışma kapsamında yapılan görüşmelerden anlaşılmaktadır. Katılımcıların bir yiyecek içecek işletmesinde deneyimleri olumlu ise, tip 1 diyabetli birey dışarıda yemek yeme faaliyetlerine tekrar katılabilmek için motive olmaktadır. Deneyimleri olumsuz olan katılımcılar ise, mecbur kalmadıkça dışarıda yemek yemeyi tercih etmemektedirler. 
Yine çalışmada katılımcılara yöneltilen görüşme sorularına alınan yanıtlar kapsamında tip 1 diyabetli bireyler istemsizce, "küçük şehirlerde yaşayan tip 1 diyabetliler" ve "büyük şehirlerde yaşayan tip 1 diyabetliler" olarak ayrılmışlardır. Küçük şehirlerde yaşadığını belirten tip 1 diyabetliler ile büyük şehirlerde yaşadığını belirten tip 1 diyabetlilerin verdikleri yanıtlar zaman zaman farklılıklar göstermiştir. Örneğin küçük şehirlerde yaşadıklarını belirten katılımcılar yaşadıkları olumsuz deneyimlerin de etkisiyle temel beklenti olarak "erişilebilirlik" (şekersiz içecek, glisemik indeksi düşük besinler vb.) konusunun ön plana çıktığını belirtmişlerdir. Bu katılımcılar, ihtiyaçları olan glisemik indeksi düşük karbonhidratların yiyecek içecek işletmelerinde bulunmaması nedeniyle, çoğunlukla yanlarında bunları taşımaktadırlar. Bu durum zaman zaman tip 1 diyabetli bireyi kısıtlamakta, bağımsız davranma veya hissetme konusundaki isteklerine engel olmaktadır. Büyük şehirlerde yaşadığını belirten tip 1 diyabetli katılımcılar ise bahsedilen ürünlere erişebilmektedirler. Ancak yanlış bilgilendirme ve yüksek fiyatlandırmadan yakınmaktadırlar. Dolayısıyla küçük ya da büyük şehir fark etmeksizin yiyecek içecek işletmeleri, ürünlere erişim sorununu çözmeli ve bu ürünlerin bulunduğu menülere ulaşılabilir bir fiyatlandırma politikası yapmalıdırlar. Bu düzenlemelerle birlikte tip 1 diyabetli bireylerin bir yiyecek içecek işletmesinde tüketim sergileme motivasyonları artacaktır.

Çalışmada, tip 1 diyabetli bireylerin dişarıda yemek yeme motivasyonlarının temel belirleyicisi olarak yemek yemekten ziyade, sosyalleşme, arkadaş ve aile bireyleriyle vakit geçirme isteği gibi genel durumları içeren motivasyon faktörlerinin ön plana çıktığı görülmüştür. Bu durumun temel sebebinin yine tip 1 diyabetli bireylerin diyet içeceklere ve glisemik indeksi düşük karbonhidratlara olan erişilebilirlik sorunun olduğu, bu ürünleri menüsünde bulunduran yiyecek içecek işletmelerinin ise fiyatlandırma politikalarının yüksek olduğu sonucuna ulaşılmıştır. Bu durum tekrar olumsuz deneyimlerin varlığını çağrıştırmaktadır.

Çalışma kapsamında elde edilen bir diğer bulguya göre katılımcılar, diyet menü içeren yiyecek içecek işletmelerinin çoğu zaman yanlış bilgilendirme yaptıklarından yakınmışlardır. Menülerinde sundukları yiyecek ve içeceklerin besin değerlerini belirten yiyecek içecek işletmeleri kesinlikle doğru bilgilendirme yapmalıdırlar. Çalışma kapsamında tip 1 diyabetli bireylerin tümü karbonhidrat sayımı yöntemiyle insülin dozlarını ayarlamaktadırlar. Dolayısıyla menüde karbonhidrat miktarının yanlış belirtilmesi, tip 1 diyabetli bireylerde kan şekeri düşmesine ya da kan şekeri yükselmesine neden olabilir. Bu durum kısa vadede çözümlenebilecek bir durum gibi gözükse de uzun vadede ciddi komplikasyonlar yaratabilir.

Ayrıca menüde sunulan yiyecekler ve içecekler hakkında yiyecek içecek işletmesi çalışanlarının yeterli düzeyde bilgi sahibi olmamaları, tip 1 diyabetli bireylerin çeşitli sorunlarla karşılaşmalarına sebep olduğu görüşmeler sonucunda anlaşılmıştır. Dolayısıyla yiyecek içecek işletmeleri menülerinde bulunan yiyeceklerin ve içeceklerin içeriğiyle ilgili çalışanlarına mutlaka eğitim vermelidir.

Tip 1 diyabetli bireylerin yiyecek içecek işletmelerinden temel beklentilerinin yanı sıra, tatmak istedikleri farklı yiyecek içecek kültürleri ve yöresel yemeklerin bulunduğu da görüşmeler sürecinde karşılaşılan konular olmuştur. Katılımcılar, her ne kadar çok sık bu faaliyetlerde bulunamadıklarını belirtseler de kamu ve özel sektörün, yöresel yemeklere menülerde yer vermesi, içeriklerinin belirtilmesi ve tanıtılması konularında birlikte hareket etmeleriyle tip 1 diyabetli bireylerin yiyecek içecek işletmelerinde tüketim gösterme düzeylerinde artış beklenebilir.

Genel olarak değerlendirildiğinde ise; tip 1 diyabetli bireylerin, en temel beklentisini erişilebilirliğin ve menü fiyatlarının düşürülmesinin oluşturduğu ortaya çıkmıştır. Tip 1 diyabetli bireylerin temel beklentisi bazında yiyecek içecek işletmelerinin menülerde yapacağı bu 
düzenlemelerin, toplumdaki sosyal katılımı üst düzeye çıkaracağı, ayrıca dışarıda yemek yemeye katılımı da olumlu yönde etkileyeceği unutulmamalıdır.

Araştırma sonuçlarına göre tip 1 diyabetli bireyler, kendilerine en uygun yiyecek içecek işletmesinin hangisi olduğuna karar verirken daha fazla titiz hareket etmek durumunda kalabilmektedir. Dolayısıyla yiyecek içecek işletmeleri, tip 1 diyabetli bireylerin işletmelerinde tüketim göstermesini bekliyorlarsa, bu kişilerinde beklentilerini göz önünde bulundurmalıdırlar.

Bu araştırmanın örneklemi tip 1 diyabetli bireylerden oluşmaktadır. Gelecek çalışmalarda farklı gruplara yönelik yapılan araştırmalar, bireylerin ayrım yapılmaksızın dışarıda yemek yeme faaliyetlerine katılımları konusunda daha çeşitli sonuçlara ulaşmayı sağlayabilecektir. Ayrıca çalışma kapsamında elde edilen bulgulara göre büyük şehirlerde yaşayan tip 1 diyabetliler ile küçük şehirlerde yaşayan tip 1 diyabetliler arasında farklılıklar göze çarpmıştır. Bu bağlamda gelecek çalı̧̧malarda her iki grupta bulunan tip 1 diyabetlilere görüşme soruları, şehirler bazında ayrı ayrı yöneltilip karşılaştırma yapılabilir.

\section{KAYNAKÇA}

Altınok, Y. (2018). Tip 1 Diyabetes Mellitusda Tibbi Beslenme Tedavisi, (Editör) Aycan, Z.: Çocuk Endokrinolojisi ve Diyabet Derneği Ulusal Çocuk Diyabet Grubu, Çocukluk Çağı Diyabeti: Tanı ve Tedavi Rehberi içinde (ss.35-40), Ankara: Buluş Tasarım.

Alvesson, M., Hardy, C. and Harley, B. (2008). Reflecting on Reflexivity: Reflexive Textual Practices in Organization and Management Theory, Journal of Management Studies, 45(3): 480-501.

American Diabetes Association. (2020). https://www.diabetes.org/diabetes [Erişim Tarihi: 13.6.2020].

American Diabetes Association. (2020). https://www.diabetes.org/diabetes/type-1 [Erişim Tarihi: 13.6.2020].

Demirkol, Ş. (2015). Yiyecek-İçecek İşletmeleri, (Editör) Zengin, B. ve Demirkol, Ş.: Turizm İ̧letmeleri, içinde (ss. 161-226), İstanbul: Değişim Yayınları.

Ersoy, G. (2004). Egzersiz ve Spor Yapanlar İçin Beslenme, Ankara: Nobel Akademik Yayıncılık.

Gillepie, S. J., Kukarnik, D. and Daly, A. E. (1998). Using Carbohydrate Counting in Diabetes Clinical Practice, Journal of The American Dietetic Association, 98(8): 897-905.

Gökşen, D., Altınok, Y. A., Özen, S., Demir, G. and Darcan, Ş. (2014). Effects of Carbohydrate Counting Method on Metabolic Control in Children with Type 1 Diabetes Mellitus, J. Clin Res Pediatr Endocrinol, 6(2): 74-78.

Güçlü Nergiz, H. (2017). Gastronomi ve Sağlıklı Beslenme, (Editör) Sarışık, M.: Tüm Yönleriyle Gastronomi Bilimi içinde (ss.125-140), Ankara: Detay Yayıncılık.

International Diabetes Federation. (2019). IDF Diabetes Atlas (9. Edition), 10-66.

International Diabetes Federation. (2020). https://www.idf.org/aboutdiabetes/type-1diabetes.html [Erişim Tarihi: 31.05.2020].

Kocatepe, D. ve Turan, H. (2012). Su Ürünleri Alerjisi, Mehmet Akif Ersoy Üniversitesi Fen Bilimleri Enstitüsü Dergisi, 3(2): 46-51.

Koyunoğu Bingöl, N. (2013). Kısa ve Hızlı Etkili İnsülin Kullanan Tip 1 Diyabetlilerde Karbonhidrat Sayma Yönteminin Kan Şekeri Regülasyonu Üzerindeki Etkilerin İncelenmesi, Yayınlanmamış Yüksek Lisans Tezi, Haliç Üniversitesi, Sağlık Bilimleri Enstitüsü, İstanbul. 
Mahan, K. L., Escott-Stump and S., and Raymond, J. L. (2012). Medical Nutrition Therapy for Diabetes Mellitus and Hypoglycemia of Nondiabetic Origin, (Editör) Alexopoulos Y, Frazier D.M. Krause's Food and Nutrition Care Process içinde (ss.675-710), Philadelphia: Saunders.

Özbek, M. N. (2018). Tip 1 Diyabette Egzersiz, (Editör) Aycan, Z.: Çocuk Endokrinolojisi ve Diyabet Derneği, Ulusal Çocuk Diyabet Grubu, Çocukluk Çă̆̆ Diyabeti: Tanı ve Tedavi Rehberi içinde (ss.4753), Ankara: Buluş Tasarım.

Özer, E. (2013). Diyabetliler İçin Hayatı Kolaylaştırma Kılavuzu, İstanbul: Hayykitap.

Patton, M. Q. (1999). Enhancing the Quality and Credibility of Qualitative Analysis, Health Services Research, 34(5): 1189-1208.

Rabasa-Lhoret, R., Garon, J., Langelier, H., Poisson, D., and Chiasson, J. L. (1999). Effects of Meal Carbohydrate Content on Insulin Requirements in Type 1 Diabetic Patients Treated Intensively with the Basal-Bolus (Ultralente-Regular) Insulin Regimen, Diabetes Care, 22: 667-673.

Ranjan, A., Schmidt, S., Damm-Frydenberg C., Steineck, I., Clausen, T. R. and Holst, J. J. (2017). Low-Carbohydrate Diet Impairs the Effect of Glucagon in the Treatment of Insulin-Induced Mild Hypoglycemia: A Randomized Crossover Study, Diabetes Care, 40(1): 132-135.

Sayan, A. (1999). Beslenme Alışkanlıkları ve Temel Besin Gereksinimleri, Atatürk Üniversitesi Hemşirelik Yüksekokulu Dergisi, 2(2): 53-65.

Sheard, N. F., Clark, N. G. and Brand-Miller, J. C. (2004). Dietary Carbohydrate (Amount and Type) in the Prevention and Management of Diabetes: A Statement by the American Diabetes Association, Diabetes Care, 27: 2266-2271.

Smart, C. E., Annan, F., Higgins, L. A., Jelleryd, E., Lopez, M. and Acerini C. L. (2018). ISPAD Clinical Practice Consensus Guidelines 2018: Nutritional Management in Children and Adolescents with Diabetes, Pediatr Diabetes. 19: 136-154.

Telek, M. (2017). Karbonhidrat Sayımını Hastaya Nasıl Öğretebilirim?, Klinik Tıp Bilimleri Dergisi, (5) 4: 5-8.

Tozlu Özhan, E. (2018). Turizme Katıllmda Engelli Bireylerin Motivasyon ve Beklentilerine İlişkin Görgül Bir Araştırma, Yayınlanmamış Doktora Tezi, Sıtkı Koçman Üniversitesi, Sosyal Bilimler Enstitüsü, Turizm İşletmeciliği Anabilim Dalı, Muğla.

Türk Diyabet Cemiyeti. (2020). http://www.diabetcemiyeti.org/c/tip-1-diyabet-hastaligi [Erişim Tarihi: 2.6.2020].

Türkiye Cumhuriyeti Sağlık Bakanlığı, Halk Sağlığ1 Genel Müdürlüğü. (2020). https://hsgm.saglik.gov.tr/depo/birimler/saglikli-beslenme-hareketli-hayat-db/Diyabet/tip-1diyabet/Diyabet-Nedir.pdf [Erişim Tarihi: 2.6.2020].

Türkiye Cumhuriyeti Sağlık Bakanlığı, Halk Sağlığı Genel Müdürlüğü. (2020). https://hsgm.saglik.gov.tr/depo/birimler/saglikli-beslenme-hareketli-hayat-db/Diyabet/tip-1diyabet/Diyabet-Tipleri.pdf [Erişim Tarihi: 2.6.2020].

Türkiye Cumhuriyeti Sağlık Bakanlığı, Sağlık Bilgi Sistemleri Genel Müdürlügü̈. (2020). https://sbsgm.saglik.gov.tr/TR,1610/diyabetin-uzaktan-takibi-icin-tc-saglik-bakanligindanuluslararasi-proje.html\#: :text=5\%20milyona\%20ula\%C5\%9Ft\%C4\%B1.-

,T.C.,7.112.000\%20diyabet\%20hastas\%C4\%B1\%20bulunuyor. [Erişim Tarihi: 18.7.2020]. 
Zipp, C., Roehr, J. T., Weiss, L. B. and Filipetto, F. (2011). Impact of Intensive Nutritional Education with Carbohydrate Counting on Diabetes Control in Type 2 Diabetic Patients, Patient Preference and Adherence, 5: 7-12. 